\title{
"HOW WILL I EXPLAIN WHY WE LIVE BEHIND A WALL?" LA ZONA (2007) AS SUBURBAN GOTHIC NARRATIVE
}

\author{
Bernice M. Murphy
}

Trinity College Dublin

\begin{abstract}
This paper argues that Rodrigo Pla's film La Zona (2007), set in a privileged, self-governing gated community in Mexico City, replicates many of the North American variety of the Suburban Gothic's most characteristic preoccupations, albeit in a Latin American setting, and with reference to specifically regional economic and political anxieties. The paper also discusses the ways in which the Suburban Gothic so often serves as a means of expressing specifically middle-class anxieties about the relationship between the privileged and the disenfranchised, in this instance, specifically Mexican anxieties about the liberties afforded to the wealthy and the ramifications of police corruption and political cronyism.
\end{abstract}

Keywords: Suburban Gothic, La Zona, Rodrigo Pla, Mexico City, Gated Community, Suburbia.

\begin{tabular}{|l|l|l|l|l|}
\hline Ilha do Desterro & Florianópolis & $n^{\circ} 62$ & p. 241-269 & jan/jun 2012 \\
\hline
\end{tabular}


242 Bernice M. Murphy, "How will I explain why we live behind a wall?”...

In this paper I will argue that Rodrigo Pla's critically acclaimed 2007 film La Zona, which is set in a privileged, self-governing gated community located next to the slums of Mexico City, replicates many of the North American Suburban Gothic's most characteristic preoccupations, albeit in a Latin American setting, and with reference to specifically regional economic and political anxieties. In particular, the film displays the subgenre's consistent focus on the relationship between the "haves" and the "have-nots" and the dramatisation in Gothic terms of middle-class fears about family and community safety. In North American popular culture, as we shall see, the suburban milieu has long served as a frequent setting for narratives of fear, repression and horror: amongst other things, the very "inbetween-ness" of the environment-the fact that it is, geographically, neither one thing nor another-makes it an ideal setting for narratives which, as so often the case in the gothic in general, probe beneath a seemingly unremarkable surface of things and find repression, corruption and crippling dysfunction festering beneath.

Though, as previously noted, it is set in Latin America, I will suggest here that La Zona nevertheless has a great deal in common with earlier North American narratives of this type, such as Shirley Jackson's 1948 novel The Road Through the Wall and Wes Craven's 1994 film The People Under the Stairs, both of which also depict the suburban milieu as a place in which vigilantism is normalised, the representatives of outside authority are sidelined, and those who do not belong are subject to the capricious excesses of the privileged. One of the principal characteristics of the Suburban Gothic, no matter what country it is set in, is that it so often dramatises in gothic form particularly middle-class concerns about the supposed sanctity and safety of the bourgeois nuclear family. In addition to 
doing all of this, I will suggest that $L a$ Zona reflects specifically Mexican/Latin American anxieties about the liberties and abuses afforded to the wealthy and the wider ramifications of police and political corruption.

Before embarking upon my specific discussion of the text, however, it is important to begin by noting that employing a concept such as the "Suburban Gothic", (which, as we shall see, has its origins in a specifically Anglo-American critical, cultural, and historical context), becomes inherently problematic when applied to a specifically Latin American context, in that it has the potential to oversimplify or gloss over the hugely significant implications of the regional, linguistic, and historical difference that the movement to an entirely different continent emphasises. This article therefore makes no claims to being able to satisfactorily define or critique a specifically Latin American (or Mexican) variety of the Suburban Gothic, but rather compares one representative local text with the North American variety of the subgenre, with the hope that it will perhaps offer a tentative starting point for further research into this area by critics whose expertise in the area of Latin American popular culture (and in this instance, Mexican cinema specifically) as well as suburban/urban studies will enable them to tackle these issues more sensitively.

Briefly, the film is about what happens when the protective cordon that protects the titular enclave is breached. Three disenfranchised outsiders seize their chance when a bill board collapses during a storm and shorts out the electric fence that surrounds La Zona, creating a makeshift ladder which enables them to climb to the other side with the aim of stealing whatever they can. However, they are disturbed in the first house that they enter by Mercedes, the elderly resident, who is murdered by one of the thieves. Two of the robbers 
244 Bernice M. Murphy, "How will I explain why we live behind a wall?”...

(including the killer) are then shot by a La Zona security guard, who is then himself accidentally killed by Ricardo (Claudio Obregón), a neighbour of the dead woman. Miguel (Alan Chávez), who at sixteen is the youngest of the intruders, flees the scene but discovers that he is trapped in the gated suburb. What's more, the local residents committee, a group of twenty five La Zona inhabitants known, ominously, as "The Assembly", which is led by the domineering, aggressive Gerardo (Carlos Bardem), know that one of the intruders is still on the loose somewhere in their community. Rather than tell the police the truth about what really happened-which would mean that they lose their much-coveted special legal status-the Assembly votes to take matters into their own hands. ${ }^{1}$ Their efforts are complicated, however, by the investigative efforts of Comandante Rigobeto (Mario Zaragoza), a seemingly incorruptible local cop, who quickly realises that their story doesn't add up and sets about uncovering the truth.

This conflict between the haves and the have-nots is hammered home even in the film's opening scene. We first see the community as reflected in the tinted windows of an expensive SUV being driven by a teenage boy, Alejandro (Daniel Tovar). Though the scene we glimpse in the windows is one of tranquil middle-class normality, Alejandro's tense expression and the fact that the windows of the car are tinted adds a sinister feel to even these early moments of the opening scene. When the camera pulls away from the car to follow a butterfly as it meanders its lazy way around the neighbourhood, we see that the houses are large, the lawns green and well tended, and that orderly children in neat uniforms walk across the spacious street in single file as one of their classmates blows a whistle (a detail that, like many in this scene, will take on more ominous resonances of repression and control as the narrative unfolds). Apart from the 
music that plays softly over the scene, and the gentle purr of the SUV's engine, the sounds that we hear are ones associated with nature, and with the outside: birdsong, the bark of a well-behaved dog, the hiss of a sprinkler system. As the SUV approaches La Zona's exit, the butterfly that has been fluttering around the edges of the frame flies over a large, ugly concrete wall topped with barbed wire and CCTV cameras.

Throughout the film, the starkness of these prison-like fortifications and the poverty of the city beyond provides a striking contrast to the manicured, pretty suburban neighbourhood, and this contrast is repeatedly highlighted within many aspects of the film's mise-en-scene. Perhaps the most obvious example of this can be seen in the fact that a neatly tended hedge, an obvious signifier of middleclass order and gentrification, lies at the base of the massive concrete wall that encircles La Zona. As the camera glides up from the hedge and over the wall, we move from what seems like a suburban utopia to a scene straight out of an urban dystopia: wicked looking coils of razor wire, CCTV cameras trained on both the neighbourhood below and the one beyond the wall, a sign that says "Peligro"- "danger," and the ramshackle, teeming city beyond. We can also hear, in the distance, the sounds of the typical cityscape, which had previously been absent. At this point, the screen fades to black for a moment, before the title-stark white against the black of the rest of the scene-appears, as though being gradually revealed out of darkness. It is a fitting beginning for a film which is, after all, at least in part about what happens when an individual (in this case Alejandro) suddenly realises that the way of life he had previously taken entirely for granted is not what it seems, and discovers that, in typical gothic fashion, a placid, peaceful exterior can never entirely conceal the rot beneath. It is a feeling that is only reinforced at the beginning of the 
very next scene, which, as will recur at frequent intervals throughout the film, is initially presented to us through the dispassionate, allseeing-eye of a surveillance camera being controlled by one of the compounds guards. The inference is a simple one: the way of life that La Zona represents depends upon keeping outsiders out, and insiders under a less obvious, but still insidious, form of control

It is the relationship between these two communities-the rich suburbanites who live in "La Zona" and those on the outside who are forcibly excluded unless they are there to serve as maids, gardeners, delivery men and security guards - that creates the central drama of the film, this being the gradually developing affiliation between Miguel and Alejandro, his sheltered contemporary, who gradually realises that the "security" he and his family have enjoyed for so long comes at an unacceptably high price.

Before I discuss the film and its social and historical contexts in more detail, however, I will first outline what the Suburban Gothic actually is, and how La Zona fits into this paradigm. Although the 1950s and 1960s saw the publication of several books exploring the impact of suburbia upon North American life and/or the literary and critical responses it inspired (such as John Keats' The Crack in the Picture Window [1957] and Scott Donaldson's The Suburban Myth [1969]), explorations of the manner in which the milieu has been depicted in the horror and Gothic genres have until recently been notable largely for their absence. This is despite the fact that many of the thought-provoking examinations of North American suburbia can be found in Gothic and horror themed novels, films and television shows.

One of the most valuable recent studies of the cultural contexts of suburbia is Robert Beuka's Suburbia Nation: Reading Suburban Landscape in Twentieth Century American Landscape and Film 
(2004) which begins by establishing the importance of the suburban environment and its status as a "borderland" space situated both physically and philosophically between the urban and the rural (Beuka 23). Beuka's discussion of suburban Gothic is however confined to his chapter on Ira Levin's The Stepford Wives (1972). In Visions of Suburbia (ed. Roger Silverstone, 1997) and The Crabgrass Frontier: The Suburbanization of the United States (Kenneth T. Jackson, 1985) the establishment of the suburbs during the post war era and their cultural and social impact is discussed from within a purely sociological/historical framework. In Edge City: Life on the New Frontier (1991), Joel Garreau examines the manner in which suburbia was critiqued in the 1950s and 1960s by commentators such as Herbert Gans, Lewis Mumford, and John Keats. Again, Gothic representations of the milieu are not mentioned.

Most current studies of suburbia are conducted from a sociological or historical perspective, as in Picture Windows: How the Suburbs Happened by Rosalyn Baxandall and Elizabeth Ewen (2000) or American Dreamscape: The Pursuit of Happiness in Postwar Suburbia by Tom Martinson (2000). Although Expanding Suburbia: Reviewing Suburban Narratives (edited by Roger Webster, 2000) discusses representations of suburban life from the late nineteenth century to the present, including fiction, film, and popular music, horror and the Gothic do not feature at all.

Traditionally, therefore, apart from Kim Ian Michasiw's rather impressionistic article "Some Stations of Suburban Gothic" in American Gothic: New Interventions in a National Narrative (1998) the subgenre has tended to be given little more than a cursory mention in the work of critics working within the horror and Gothic fields, as in Stephen King's discussion of Anne Rivers Siddon's 1976 novel The House Next Door in Danse Macabre [1981]) and when Jerome 
Hogle refers to Poltergeist as "the epitome of Suburban Gothic" in The Cambridge Companion to Gothic Fiction (2002). The Suburban Gothic in American Popular Culture (2009) therefore attempts to provide a theoretical and historical framework for the concept by providing the first sustained examination of the manner in which American suburbia has been depicted in Gothic and horror films, television and literature from 1948 to the present, and by outlining the specific characteristics and theoretical components of the subgenre.

Briefly, put, it is my contention that the Suburban Gothic is a subgenre concerned with dramatising the fear that even the most ordinary-looking neighbourhood, or house, or family, has something to hide, and that no matter how calm and settled a place looks, it is only ever a moment away from dramatic (and sinister) incident. In its specifically North American incarnation the subgenre reflects the anxiety that the rapid change in lifestyles and modes of living which took place in the 1950s and early 1960s caused irreparable damage, not only to the landscape, but to the psychological state of the people who moved into the suburbs and broke with the old patterns of existence. ${ }^{2}$

In the Suburban Gothic, one is almost always in more danger from the people in the house next door, or one's own family, than from external threats. Horror here invariably begins at home, (or at least very near to it), and in that sense the subgenre continues the uneasy fascination with the connection between living environment and psychology which helped reinvigorate the haunted house story in the mid-twentieth century. As in La Zona, which focuses on the relationship between two adolescent boys, one of whom (Miguel) will ultimately be murdered by the enclave's residents, the child or teenager under threat is a common plot trope of the Suburban Gothic. So too is the destabilising spectre of the suburban youngster turned murderer and the suburban parent(s) turned avenging vigilante, 
which again, is exactly what happens here. Property prices, DIY repair costs and the loss of social standing are often just as disturbing to the Suburban Gothic protagonist as more obviously sinister threats. In La Zona, the Assembly members seem more alarmed by the potential loss of their "special" legal status than by the accidental death of the security guard, the murder of one of their own, and the shooting of Miguel's accomplices. The most characteristic response to uncanny or disruptive events in the Suburban Gothic is almost always to close the curtains and keep quiet about it. A similar policy of keeping things under wraps-this time, within the confines of the entire neighbourhood, and not just the nuclear family—also becomes a major plot point in La Zona. Early on, Gerardo declares "We'll take care of it" ("We" meaning the Assembly) and the police are seen as a nuisance to be ignored, or paid off.

More than anything else, the Suburban Gothic is concerned with exploiting a closely interrelated set of binary oppositions, in which the assumptions that lie at the heart of the so-called "Suburban Dream" are inverted/subverted. In its positive incarnation, the suburban neighbourhood is perceived as offering the chance for the upwardly mobile young family to have a home of their own, and as the utopian setting for a better life in which one will be surrounded by welcoming and financially secure neighbours who have aspirations analogous to your own. In the Suburban Gothic text, homeownership means crippling debt and/or financial ruin; the homely becomes the haunted (or to paraphrase Freud on the Uncanny, the heimlich becomes the unheimlich), and the utopian dystopian. In addition, the nice people next door always have something terrible to hide, and the assumption that the milieu will provide a safe place for youngsters to grow up in is undermined by the fact that such a child-centered 
environment provides an obvious hunting ground for paedophiles and child murderers.

Similarly, on one hand, the suburb is seen as a bucolic refuge from the overcrowded and polluted city: on the other, the construction of the suburban neighbourhood necessitates the destruction of the countryside and consumption of increasingly scarce natural resources, while also rendering those who live there entirely dependent on their cars. Finally, the "Suburban Dream" is posited on the belief that such neighbourhoods are uniquely insulated from the dangers of the outside world, whereas in the Suburban Gothic, the most dangerous threats come from within, not from without.

Accordingly, La Zona exhibits many of these characteristics, in particular the sense that the suburban neighbourhood is a "safe" place that excludes the myriad threats seen to exist in the world beyond its borders-accompanied by the suspicion, that there may be worse things to worry about inside the suburb than outside. It is a trope heightened here by the fact that, as emphasised by the film's mise-enscene from the very beginning, La Zona is a specifically gated suburb, in which even more emphasis than usual is placed on security and exclusion than usual.

Perhaps one of the most significant factors in explaining why suburbia has long attracted such mixed feelings is the fact that even the very concept of suburban development implies a falling between two geographical stools. The suburb is, after all, an in-between space by definition: located beyond the heart of a town or city, yet still existing within its urban orbit. The geography of the typical suburb has also tended to be intermediate between that of the town centre and of the countryside. Given that the gothic so often arises from the gaps between what something is and what it is not, it is perhaps hardly surprising that from the beginnings of mass suburbanization, 
the milieu has proven a more than fitting venue for horror and gothic fictions exploring the often malevolent and frequently subversive flipside to the pro-suburban rhetoric espoused by the government, big business, land developers and the advertising industry.

The definitions given here refer specifically to the North American Suburban Gothic, which is rooted in the conflicted response many Americans had to the transformations that followed the Second World War. However, significant Suburban Gothic traditions exist in other, predominantly Western, countries such as Canada, Australia, New Zealand, and the United Kingdom. La Zona is, I would suggest, a perfect example of a specifically Latin American Suburban Gothic narrative. Whilst some obvious and inevitable differences exist between the various national variations of the subgenre, it is still the case that to a greater or lesser extent the characteristics cited above can also be found in suburban gothic texts from around the world, albeit with the infusion of specifically local cultural, economic, social and political anxieties. La Zona does exactly this by focusing on the specifically middle-class fears about "invasion" from without and coercion from within which often surface in the more prominent North American variety of the subgenre, whilst simultaneously critiquing the increasing preference for segregated enclaves which exists in Latin America generally and, as in this case, the sprawling metropolis of Mexico City specifically.

A gated community is defined as "A housing development that restricts public access, usually through the use of gates, booms, walls and fences [...] residential areas may also employ security staff or CCTV systems to monitor access" (Bagaeen and Uduku 1). Though La Zona is set in Mexico City, a metropolis with many such neighbourhoods, it should be noted that gated communities are by no means a specifically Latin American phenomenon. In 
252 Bernice M. Murphy, "How will I explain why we live behind a wall?"...

North America, such enclaves have been becoming increasingly commonplace since the early 1980s, in part as a reaction to growing fear about the direction that the country is going in, and due to the fact that "Many feel vulnerable, unsure of their place and the stability of their neighbourhoods in the face of rapid change. This is reflected in an increasing fear of crime that is unrelated to actual crime trends or locations, and in the growing number of methods used to control the physical environment for physical and economic security" (Blakely and Snyder 1).

As Bagaeen and Uduku further demonstrate, such developments have spread all over the world, from North America, to China, South Africa, Israel, New Zealand and all over Latin America. In fact, anywhere that there is a significant gap between the "haves" and the "have-nots", it is likely that a gated community of some description will spring up, because as Setha Low has noted,

Gated communities respond to middle-class and upper-middleclass individuals desire for community and intimacy and facilitate avoidance, separation, and surveillance. They bring individual preferences, social forces, and the physical environment together in architectural reality and cultural metaphor. (48)

All of these elements can certainly be seen at work in La Zona, which presents a dystopian vision of life in the Mexico City of the very near future that is in fact only a very slightly exaggerated version of reality as it already exists both there and in cities all over Latin America. As Pla has said himself of the film,

You could say that La Zona is the story of an armed robbery gone wrong. In truth though, it is a story about a broken and divided society, a story of two worlds that fear and hate each 
other. What is to be done when the inefficiency and corruption of those who are supposed to tender justice leave us having to fend for ourselves? ${ }^{3}$

Although gated communities the world over tend to share the characteristics described by Low, there is a specific historical and cultural resonance to that seen in La Zona which is essential to achieving a full understanding of the film. In her article on the historical roots of gated communities in Mexico City, Diana Sheinbaum notes that fortified enclaves have been a feature of life there since the first urban grid was laid out over the remains of Tenochtitlan, the ancient capital of the Mexicnempire, by Spanish conquerors in the early sixteenth century (80). While the centre of the new city was reserved for Spaniards, the outskirts became the place where the native inhabitants, the dispossessed, the conquered, were expected to live. This policy of ethnic and racial separation was later further reinforced by the political and judicial division of the city into two "republics", each with separate laws, tribunals and civil and ecclesiastical authorities, and strengthened by a deliberate disparity between the different types of architecture found in each sector and by the superior infrastructure created in the central zone (Sheinbaum 80). With the economic modernisation that took place between 1858 and 1910, Mexico City rapidly expanded due to a massive influx of migrant workers, and the population more than doubled, from 200,000 to 450,000, while the city itself grew from 8.5 square kilometres to 40.5 (Sheinbaum 84 ). As in previous centuries, however, the real power still rested in the hands the economic elite, in this instance a small group of European and American born financiers who controlled much of the cities industry, commerce and real estate (Sheinbaum 84). 
254 Bernice M. Murphy, "How will I explain why we live behind a wall?”...

In a pattern that would be replicated in major cities all over the world, the affluent moved from the inner city-put off by the rapid growth in population and by associated health, infrastructure and sanitation problems-and settled instead on the western periphery of Mexico City, particularly in the Juarez and Roma neighbourhoods, all of which featured large, European-style mansions and spacious avenues (Sheinbaum 84). Though the city's growth was briefly arrested by the 1910 Mexican revolution, it soon started up again, and the differences between the richer and poorer parts of the city became ever more pronounced. It was a trend further accelerated by the massive economic growth that characterised the latter half of the twentieth century, when the urban population increased by a massive $345 \%$, and the wealthy concentrated themselves in peripheral neighbourhoods that resembled "upscale American suburbs". New street patterns provided exclusivity and privacy by restricting free circulation and access, and dead ends and cul-de-sacs-all of which are a prominent feature of the layout of Pla's fictional neighbourhoodwere further employed to this end (Sheinbaum 87).

In recent years, gated and access-limited neighbourhoods have in fact become a key part of the real-estate market throughout South America, with increasing globalization and the fear of criminality being given as the two main reasons behind their proliferation (Janoschka and Borsdorf). ${ }^{4}$

As seen in La Zona, there is a powerful perception that the government and its institutions are both ill-equipped and ill motivated to deal with criminal behaviour. Indeed, Mexico's long-running war between the drug cartels and the state has become even more fierce during the presidency of Felipe Calderón (2006 -) and continues to highlight the inability of the federal authorities effectively to deal with a criminal insurgency that has cost tens of thousands of 
civilian lives. Furthermore, "In many Latin American cities crime, and violent crime in particular, seems to be out of control" (Hojman 33). The widespread lack of faith in the police which exists in many countries in Latin America is also a result of their being used as a tool against the people by repressive and corrupt political regimes. As Mark Ungar has observed, "As in most other countries, real police modernization in Latin America occurred in the twentieth century. Unlike the US and Europe, though, it was undertaken primarily by authoritarian regimes to integrate police forces into highly repressive security apparatuses. Part of the regional democratisation of the $1980 \mathrm{~s}$ and 90s was, of course, the rejection of the state power associated with that repression" (27). It is hardly surprising then that the wealthy, who of course have the motivations and the means to do so, should decide to take their security into their own hands, nor that:

Residential developments that have physical protection and access controlled entrances have become the norm rather than the exception. In the past, segregation was not as tightly related to a feeling of insecurity, but rather to convey a certain status. In this sense, one of the features that differentiate new housing schemes from old is the presence of protection devices such as walls, fences, secured entrances, armed personnel and video cameras, all of which restrict access to the gated enclaves. (Sheinbaum 88)

Ungar observes that the most rapidly growing sectors of the business concern the guarding of entrances and common areas of gated communities, of which there are now very many indeed: "In Mexico City, for example, about 750 gated communities with about 50,000 housing units were formed between 1990 and 2001" (23). And of course, the more gated communities there are, the more 
need for private security there is, and the state's control over such neighbourhoods becomes ever more tenuous. It is a breeding ground for vigilantism:

Most starkly exhibiting how private security fills the vacuum of state control is the phenomenon of vigilantism. Vigilante actions by gangs, death squads, private militias, and other groups have long existed in Latin America, but they are now embedded in the region's democratic regimes. The number of lynching's, and justifications for them, have risen dramatically since the mid1990 s, even when taking account of better documentation, with about 6,000 killings a year in Latin America [...] often with the support or collusion of police officers, most vigilante actions are carried out by citizens, from spontaneous gatherings to organised "committees". (Ungar 24)

As briefly mentioned earlier, vigilantism and mob violence, key tropes in La Zona, are also one of the most notable recurrent features of the North American variety of the Suburban Gothic, even if the contempt towards law enforcement and other state apparatus seen there is never quite as strong (for obvious historical reasons; i.e., North America has never been a dictatorship).

For instance, Shirley Jackson's The Road Through the Wall is about an upscale San Francisco neighbourhood which has a fair bit in common with that seen in La Pla's film. It isn't a gated community - there are no armed guards, cameras or electric fences here-but Cabrillo is separated from the poorer neighbourhood nearby by a wall which acts as a marker of social and economic segregation. Tellingly, it is when the wall itself starts to come down due to construction work that the community begins to turn on itself, a trend that intensifies when a little girl from the neighbourhood is found dead in suspicious circumstances. Although the true cause of 
her death is left ambiguous-it could be murder, or an accidentthe "crime" is soon blamed on a disturbed thirteen year old boy, and the community becomes a posse determined to hunt him down. Ultimately, he kills himself rather than face them.

Richard Matheson's classic 1954 apocalyptic suburban-set novel I Am Legend is about a middle-class everyman, Richard Neville, who is seemingly the last human left alive in a world populated by bloodthirsty ghouls who have been transformed from normal people by germ warfare. He takes it upon himself to hunt down and kill as many of them as he can, even those who were once his friends and neighbours, and an ongoing strand of the plot concerns his now deadly rivalry with his next-door neighbour. Unlike as in two of the three film adaptations of the story, in the novel, he remains in his suburban neighbourhood. Neighbour also violently turns against neighbour in two classic The Twilight Zone episodes that allowed series creator Rod Serling to critique mob violence and suburban selfcenteredness. In "The Monsters are Due on Maple Street" (1959), a power failure and rumours of alien invasion again cause neighbour to violently turn against neighbour: much the same thing happens in 'The Shelter', when an unfounded UFO scare exposes the egocentric nature of an otherwise idyllic neighbourhood.

Otherwise "civilized" suburbanites violently turn upon more obviously villainous outsiders in no less than four different Wes Craven movies: The Last House on The Left (1972), The Hills Have Eyes (1977), A Nightmare on Elm Street (1984) and Red Eye (2005), while the grieving father of murder victim Susie Salmon in Alice Sebold's 2002 bestseller The Lovely Bones similarly seeks (unsuccessfully) to wreak vengeance upon the next-door-neighbour he rightly suspects of involvement in her death. The release of a convicted child molester and suspected murderer in Tom Perrotta's Little Children 
(2004) also leads to violence and vigilantism, whilst an (innocent) man is hounded out of a Washington suburb in Suzanne Berne's $A$ Crime in the Neighbourhood (1997). The closely related tropes of the angry mob, and of the middle-class community that resorts to vigilante violence in order to enforce its own sense of security and safety is therefore very common one in North American suburbanset popular narratives.

What is particularly interesting about La Zona is the fact that while, as in many of the narratives just cited, the community bands together to hunt down someone who has violated their laws and mores, the individual being sought here is himself a teenager. Contrastingly, the target of middle-class vigilantes in the other examples is always an adult (or adults) who has harmed (or is believed to have harmed) local youngsters. As we shall see, what glimmer of hope there is for the future in La Zona-and it is only a glimmer-emerges from the relationship between Miguel and Alejandro. Both display a humanity that is otherwise lacking in most of the adults around them. Often, in the Suburban Gothic narrative it is the adults who come off worst and their children who suffer most for their mistakes, but also appear in the best light. It's a tendency that can also be seen in another Wes Craven film, this time one that has much in common with La Zona: The People Under the Stairs (1991).

The basic premise is fairly similar. Fool (Brandon Adams), a young black boy, lives in a slum neighbourhood of LA owned by the Robesons, deranged (white) siblings who live in a heavily fortified suburban home. He reluctantly agrees to help a seasoned thief named Leroy (Ving Rhames) break into their house. The two are attacked by vicious dogs and Leroy is shot and killed by the Robesons, murderous psychopaths whose activities as heartless landlords are just the tip of the iceberg. Like Miguel, once he has 
illicitly gained entry to the privileged suburban milieu he initially intended to rob, Fool discovers that leaving alive is a much more difficult undertaking. Whereas La Zona's security apparatus is dominated by the visible tools of surveillance-the presence of multiple CCTV cameras and frequent security patrols is emphasised by Pla, as is the fortified wall that surrounds the community-Fool's progress through the Robeson house is more like a cartoonish guerrilla war. The Robeson's security techniques are more overtly aggressive, and feature elaborate booby traps and the liberal use of firearms (admittedly, also a feature of the La Zona, but there downplayed in comparison). Fool's escape is complicated when he discovers a girl his own age, Alice, who has been kept prisoner by the couple for years, and raised as their "daughter". What's more, there are dozens of emaciated young men in the basement, all of whom had previously been kidnapped in order to be "sons", but were (literally) silenced by having their tongues cut out and by having been chained underneath the main house when they failed to "behave".

The People Under the Stairs is a much more cartoonish, fairy-tale like, and satirical story than La Zona, and certainly doesn't have the air of realism that Pla's film does. But in their own way, each film suggests much the same thing: that the abuse of power and privilege is just as damaging for those who are in charge as it is for those who find themselves subject to this authority. Craven's film, which focuses on a single household, makes some pertinent points about the racial and economic divisions that still exist within North America (and were particularly obvious in Los Angeles during the 90s), but it is also about the potential for abuse and corruption that exists within the middle-class nuclear family itself (a concern in his work from the The Last House on the Left onwards). La Zona focuses on an entire 
neighbourhood, and, by extension, on Mexican society, but as in Craven's film, the middle-class family is critiqued also.

Of particular importance in this regard is the relationship between Alejandro and his father, Daniel (Daniel Giminéz Cacho). Daniel is a seemingly, reasonable man, an architect, who nevertheless acts throughout the film as right-hand man to the brutish Gerardo. When the alarm is raised following the break in, he rushes to the scene, and, tellingly, allows the curious Alejandro to come along as well, despite the objections of his wife, Mariana (Maribel Verdú). It is significant that Alejandro's sixteenth birthday occurs the next day, for clearly, his father intends to begin introducing him to what seems to be the specifically masculine responsibilities of life in La Zona. Though the Assembly consists of both men and women, the men seem to be in charge, and security concerns on the ground their sole responsibility: their authority certainly supersedes that of the security guards that they employ.

Alejandro's naïve view of life in the neighbourhood is shaken by the sight of Mercedes' corpse and that of the others, and even more so by the cover-up undertaken by his father and the others, who dismiss the idea of bringing in outside authorities. "I voted the way I did because the police are useless", Daniel later tells his son, before pausing to explain just why it is that he moved his family to La Zona in the first place. It seems that "on the outside" his brother was shot in broad daylight, and bled to death on the street because the police took too long to arrive. Though the killers were eventually arrested on the basis of Daniel's eye witness testimony, they were soon freed, and savagely beat him as retribution. "I'm only alive today because of the neighbours", he adds. Daniel's story strongly resembles that of Edward Walker, founder of the similarly insular "utopian" rural community in M. Night Shyamalan's The Village (2004). Walker, along with every 
other senior member of the village, has also been a victim of violent crime; in fact, we find out later on that the community's elders met as members of the same support group. Determined to ensure that their own children grow up protected from immorality and crime, the elders have, quite literally, created their own world, one that seeks to replicate much older, and supposedly, more innocent pattern of life. Instead of a wall, they have the forests which surround them, and an imaginary threat which deters curious youngsters from straying off the beaten path. A similar dynamic, albeit expressed in an even more disturbing fashion, can be seen in the 2009 Greek film Dogtooth (Kynodontas), in which a trio of young adults-siblings-are deliberately infantilised and kept entirely separated from the outside world by their insanely controlling parents. The garden in which they spend their days is, La Zona like, surrounded by a high wooden fence and a remote controlled gate through which their father enters and exits every day in his expensive car, and their child-like mental states are emphasised by the fact that they always appear dressed in neat white shorts and t-shirts. In La Zona, the contrast between the sheltered, well-cared for Alejandro and slum kid Miguel is similarly heightened by the fact that Alejandro wears his neat school uniform for much of the film, whilst Miguel is always seen in untidy casual wear, which gets more and more bedraggled as his situation grows more desperate.

As in La Zona, the community's rules are created and enforced by a committee of older citizens with privileged knowledge. It is a dynamic also seen in the British horror-comedy Hot Fuzz (2007), in which a hot-shot police officer finds himself transferred to a sleepy village of Sandford, which claims to be completely crime free. It eventually turns out that the reason why the crime rate is so low is that the local neighbourhood watch committee, which consists of 
262 Bernice M. Murphy, "How will I explain why we live behind a wall?”...

various respected local luminaries (including the local pub landlord, doctor, and innkeeper), have been murdering anyone they deem to have jeopardised their longstanding success in the national "Village of the Year" competition-a ruse aided by the fact that the local police officers are completely incompetent, and their commander is the leader of the vigilante group.

In both of these films, as in La Zona, Dogtooth, and The People Under the Stairs, children come to realise that their parents are not quite what they seem, and that the way of life they have unthinkingly accepted all of their lives comes at considerable cost. With Fool's help, the terribly abused and timid Alice in Craven's film finds the strength to stand up to the monsters who have kept her locked away from the rest of the world. Ivy Walker (Edward's daughter) in The Village is eventually told by her father that the fearsome "creatures" who inhabit the woods beyond their settlement are in fact not real, although unlike the other protagonists mentioned here, she is never quite told the full story. By the end of the film she still has no idea that the village is in fact a historical anachronism, but because the motives of the elders are presented to us as benign, this withholding of knowledge is, problematically, posited as a good thing. Bumbling PC Danny Butterman in Hot Fuzz, however, ultimately plays a crucial role in exposing and defeating the corrupt, murderous local powerbrokers led by his father (who has acted in this manner because he blames the death of his wife on the anti-social behaviour of outsiders), and the eldest daughter in Dogtooth (as with all of the "children" her name is never given) finally manages to escape the confines of the family home, though with ambiguous consequences.

Similarly, much of La Zona traces the process by which Alejandro goes from blithely accepting the way things are run to directly challenging them. The film makes it clear that in the normal 
run of things, boys are all too eager to imitate their fathers, and that this can lead them to unthinkingly replicating their way of seeing the world as well. Alejandro's friends, who like him, all attend school within the enclave, form their own posse dedicated to hunting down the intruder because, as they put it, "We have to defend La Zona". Tellingly, the Assembly actually meets in a room inside the boy's school, emphasising the close relationship between their activities and those of the rest of the community.

While listening in on their meeting, the boys hear the committee vote to "hunt down the killer", with only one dissenting voice, that of a resident named Diego (Andrés Montiel). Their decision not to bring in the police is compounded by the monstrous lie concocted for the widow of the guard. She is told that her husband shot himself and that if the authorities discover the truth, she won't get any insurance money. Tellingly, though he looks deeply uncomfortable, Daniel is entirely complicit in this exchange, which, like the scene in which Miguel's frantic mother tries to gain entry to La Zona, illustrates the massive power imbalance that exists between those who live within the suburb and those who do not. Though Daniel eventually forces the others to allow the widow to have custody of her husband's body, this act of relative mercy doesn't mitigate the fact that he is an important part of the repressive regime that controls the community, and is complicit in their belief that any privilege can be purchased if one has enough money to spend and powerful friends on the outside.

It is while looking for a harpoon that he can brandish while participating in their "hunt" the next day that Alejandro accidentally discovers the hungry, terrified Miguel huddled in the basement of the family home. Though he initially acts aggressively towards the interloper, the fact that Miguel is a boy of his own age has an impact, and he keeps his discovery to himself. Later, Miguel tells Alejandro 
264 Bernice M. Murphy, "How will I explain why we live behind a wall?”...

what happened on the night of the break-in, and of how he became caught up in events beyond his control. This is the first time that we, the audience, have also seen the full sequence of events, thus placing us very much in Alejandro's perspective at this moment. Though he initially just wants Miguel to leave, as the film progresses, Alejandro gradually becomes more involved with the other boy, feeding him, clothing him, and eventually conspiring with him to try and find a safe route out. The problem is, Gerardo and the Assembly have by now created a repressive state within the enclave. He even spouts chilling pronouncements like "The most important thing is security for everyone" and "The minority complies with the wishes of the majority." This means that those, who, like Diego, have revealed themselves to be "dissenters" are visited by a threatening delegation wanting to know who has called the police. Family members even begin to control each other, as we find out when Ricardo, the old man who shot the guard, confides to Daniel that "My wife is watching me". The presence of the community's CCTV camera's is also highlighted with more intensity by more and more shots of the community presented to us as seen through their electronic gaze.

In essence, then, the initial incursion into La Zona made by Miguel and his accomplices has accelerated the enclave's descent into all-out fascism, a process that soon engulfs initially well-meaning but fundamentally weak individuals like Daniel. It is a development made possible not only by the tools of enforcement and authority that the Assembly commands on the inside, but also by the power that they can exert on the outside, thanks to the corruption and inadequacy of the wider Mexican state.

This point is best illustrated by the depiction of Rigoberto. For much of the film, it seems as he will conform to a familiar, but comforting stereotype: that of the maverick cop determined to uncover 
the truth and dispense justice above the objections of his morally compromised superiors. Rigoberto puts Gerardo and the rest of the Assembly on their toes by making it clear that he's on to them; he acts upon the plea for help made by Miguel's mother (although his blunt observation that "Your missing Miguel is a thief" does hit a jarring note, and contrasts with the quiet dignity of her rejoinder that " $\mathrm{He}$ is my son"), and when told that "These documents give us special status", by an assembly member, responds, "Do they also give you permission to commit murder?" Ultimately, however, Rigoberto proves to be just as weak and flawed as the other representatives of authority seen in the film. He is betrayed both by his superiors and by his partner (who essentially sells him out), and is unable to act contrary to the wishes of his superiors because of his past record of brutality.

Indeed, Rigoberto's climactic inability to act provides the film with its most chilling scene of all. Miguel, who has been told by Alejandro that his only way out will be by hiding in the garbage trucks that leave that morning (and which, have, ominously, already ferried away the bodies of his companions), is detected by the security cameras, and again chased up and down the street. Seeing the police car containing Rigoberto, his partner, and the politician, Delegate De La Garza, who has ordered them to drop the whole thing leave, Miguel runs after them, pleading them to stop and save his life. Rigoberto slows for a moment, but is told by the delegate to drive on. "Save him now, you'll have a murderer tomorrow" the De La Garza says. And so they leave Miguel behind to be "dealt" with by the citizens of La Zona, who kick him to death in the middle of the street, all the time once more impassively watched by CCTV cameras.

Compounding the horror of the situation is the fact that Miguel is actually caught and handed over to the mob by Daniel, who, with this despicable act, completes the transition from conflicted observer 
to active participant in the Assembly's misdeed. Making the scene all the more brutal is the fact that, when Rigoberto drives out of the gate, knowing that he is condemning Miguel to death, the boy's mother, knowing what their departure means for her boy, bangs on the car window and demands to know "How much did you get for my son's life?". "You should have raised him better," Rigoberto answers, and exits the car in a blinding rage, before punching her repeatedly in the face. Significantly, this confrontation takes place just outside the confines of La Zona, and as Rigobetro's attack concludes, we yet again get the insertion of a shot seen from the perspective of the enclave's ever-present cameras. What we have here is a tool of the state who, as he puts it, for once tried to do right, but was prevented from doing so by the sorely compromised institutions that exist around him and by his own moral weakness, and so has again resorted to brutal type.

Though La Zona therefore concludes on a notably depressing note, there is, as in several of the North American films previously mentioned, a suggestion that, thanks to the next generation, things will not always be the way that they are. Alejandro goes from being a spoiled, sheltered and immature child to a courageous young man who is willing to defy both his father and the repressive regime that they live under. His brief encounter with Miguel has made him realise that those who live beyond the boundaries of La Zona are people too, and that money and power should not be a licence to behave in whatever way you like.

In addition, Alejandro is able to use the same technology that facilitates La Zona's containment culture-the video camera-as a tool for possibly creating future dissent. Before Miguel leaves the basement on his final, ill-fated bid for escape, Alejandro gets him to tell his story to camera-the camera that he has just received for his birthday. Alejandro then gives his father a copy, and we see him 
weeping as he watches the tape which reveals that the intruder whose death he has just colluded in was nothing more than a terrified boy. In the final moments of the film, we are returned to the very opening of the film, as Alejandro drives the family SUV out of the compound. This time, we know for sure that despite the orderly, idyllic seeming surroundings, La Zona is a place where terrible acts have taken place, and privilege equals the denial of humanity to those who are less materially fortunate than oneself. Rather than let Miguel be disposed of with the communities garbage-a true sign of contemptAlejandro smuggles his body out in the trunk of the SUV (a scene initially shot in the cold, early-blue light of early dawn, which then transitions into the falsely cheery sunlight seen at the very start of the film). This time, as the scene with which the film opened once more unfolds before our eyes (but with a very different resonance), there is no non-diegetic sound, only that which Alejandro can hear from inside his vehicle, which emphasises his profound isolation from the community around him, as well as the tense nature of his poignant errand. As the heavy electronic gates swing open, the last shot of him seen in La Zona is, fittingly, a prolonged close-up from the perspective of yet another security camera. At this point, the score-once again a sombre piano piece, which suggests just a hint of hope for the future this time-kicks in once more and continues, as Alejandro drives into the slums and pays for his friend to be buried in a graveyard, affording him at least some semblance of a decent committal. He also rings the judge who helped grant the community special status in the first place, presumably in order to tell him the full story. In the film's final moments, it is once more night time, and Alejandro stands eating at a food stand in the city as the strains of Sargento Garciía's "Yo me voy pa' la cumbia", first heard in the background of the scene, then rising to play over the end credits, are 
heard: in a clue that perhaps provides further insight into his new mindset, they include the repeated refrain: "Me voy, me voy, yo me voy" ("I'm going, I'm going, I'm going").

For now, life in La Zona may continue to go on as "normal", but thanks to the relationship between two boys from opposite sides of the wall, things could well change in the future. As Diego, the sole dissenting voice within the Assembly, states while looking at his little boy playing in the garden, "You know, I was thinking, when my son grows up and asks me, how will I explain why we live behind a wall?" The key, of course, is not to build a wall in the first place, and to tackle the inequality and injustice that make seem to make a barrier separating rich and poor necessary. Alejandro's actions at the end of the film suggest that the will to make these changes may be growing, even within the community itself. La Zona may not be a law unto itself for much longer.

\section{Notes}

1. The exact details of La Zona's special status are never explicitly spelled out, but it seems that the enclave, to a certain extent, has been granted the right to exist as a self governing entity with its own borders and security forces-a right which, we are told early on will be revoked if violence takes place within its precincts: "In the event of violence, La Zona residents will automatically lose all the special rights the law grants them".

2. This section is an extract from The Suburban Gothic in American Popular Culture in which I discuss the sub-gene in much more detail.

3. Fromhttp://www.diversitytoolkit.org.uk/rainbow/rainbow/ rainbowcasestudies/lazona/

4. http://www.uibk.ac.at/geographie/personal/borsdorf/pdfs/buch_gc_-_ janoschka-borsdorf_abgabeversion.pdf (Both accessed November 2011) 


\section{References}

Bagaeen, Samer, and Uduku, Ola, eds. Gated Communities: Social Sustainability in Contemporary and Historical Gated Developments, London: Earthscan Publications, 2010.

Blakeley, Edward, J. and Snyder, Mary Gail. Fortress America: Gated Communities in the United States, Brookings Institution Press, 1999.

Hojman, David E., "Inequality, Unemployment and Crime in Latin American Cities" Crime, Law and Social Change 41: 33-61, 2004.

Low, Setha, "The Edge and the Center: Gated Communities and the Discourse of Urban Fear" American Anthropologist, New Series, Vol. 103, No.1 (Mar 2001): 45-58.

Murphy, Bernice, The Suburban Gothic in American Popular Culture, Basingstoke: Palgrave Macmillan, 2009.

Roitman, Sonia and Giglio, Monica Adriana, "Latin American Gated Communities: The Latest Symbol of Historic Social Segregation" Gated Communities: Social Sustainability in Contemporary and Historical Gated Developments, London: Earthscan Publications, 2010. 63-78.

Sheinbaum, Diana, "Gated Communities in Mexico City: A Historical Perspective" Gated Communities: Social Sustainability in Contemporary and Historical Gated Developments, London: Earthscan Publications, 2010. 79-92.

Ungar, Mark, “The Privatization of Citizen Security in Latin America: From Elite Guards to Neighborhood Vigilantes" Social Justice, Vol. 34, Nos. 3-4 (2007-08), 20-27.

[Received in 09/11/2011. Approved in 14/05/2012] 
